\title{
CHALLENGES CONFRONTING NIGERIA INDIGENOUS CONSTRUCTION ENTERPRISES
}

\author{
Olusegun Emmanuel Akinsiku \\ Department of Quantity Surveying, Faculty of Environmental Sciences, University \\ of Lagos, Akoka, Lagos, Nigeria. \\ E-mail: *oakinsiku@unilag.edu.ng
}

\begin{abstract}
Construction activities in Nigeria are dominated by foreigners' managed construction enterprises. These companies constitute less than 5 percent of the number of construction enterprises in Nigeria; however, they are involved in over 95 percent of high net-worth construction activities. Nigeria Indigenous Construction Enterprises (NICE) are faced with numerous challenges that have limited their performances. This makes construction clients to patronize foreigners' managed construction firms because of the flaws in the performances of NICE. There have been measures on how to make NICE relevant, but most attempts have achieved little or no success. This study was aimed at examining the challenges of NICE in the face of the present scenario and to proffer ways of possible improvement. Primary data were collected by administering a structured questionnaire to both clients and contractors who are involved in the day-to-day construction activities. Data collected were analyzed using descriptive statistics, mean score and Kruskal-Wallis test. The study identified 25 challenges of NICE and 18 ways of improving NICE performance through careful literature reviews. The analysis of the total ranking among stakeholders revealed that limited technical expertise, insufficient profit on projects and delay in the payment of contractors for work done were the highest-ranked challenges. Application of project management techniques in construction activities, quality control of materials and improving production capabilities were the most important means of improving NICE performance as identified. The findings of this study will help to improve the competitiveness of indigenous contractors if well implemented as it will help to reduce the cost of construction as the competition nest for performing contractors will be widened.
\end{abstract}

Keywords : Capacity constraints, competition, patronage, performance

\section{INTRODUCTION}

Construction action according to Windapo (2013) is a complex interplay of people, tools, equipment, and materials coordinated by communication and paid for with money. The complexities of these actions require a sophisticated system of coordination to ensure that work is undertaken correctly. In Nigeria, there have been grave concerns over the poor performance of construction projects which is partly due to the selection of the wrong contractor to carry out construction works. The industry's problem in developing countries of which Nigeria is one according to Ogunlana, Promkuntong, and Jearkjirm (1996) are problems associated with inadequate infrastructures, problems associated with clients and consultants, problems caused by contractor's incompetence and so on. In a bid to stem the tide of the incessant poor project performance, majority of the "limited" high value-end construction projects are executed by foreigners' managed construction enterprise while a larger number of small value-end construction projects are executed by small and medium-sized construction enterprises, usually indigenously managed firms (Idoro, 2004). This system limits the patronage of indigenous contractors to majorly small value-end projects which impose little or no challenge in terms of technical abilities which may result in capacity development. This system sometimes results in these indigenously managed construction enterprises to run of business as the result of little or no patronage.

The reasons adduced for the award of high net-worth construction projects to foreigners' managed construction enterprises in Nigeria is because they are considered to be technically and managerially superior, efficient in project execution, easy access to project financing and management (Ogbebor, 2002; Oseni, 2002; 
Akintude, 2003). Indigenous contractors have over the years being plagued with poor project performance in terms of meeting completion dates, work quality and capital management which has often led to bankruptcy and in extreme cases and project abandonment. Most indigenous contractor's complete construction contracts at sums more than the initial contract sums and far above the pre-planned completion time (Idoro, 2004).

The inexperience of proprietors of construction firms and their inability to hire permanent staff do endanger them to business failure. Lack of effective management, poor management accounting, lack of profits, inaccurate estimating, and underpricing are primarily responsible for contracting business failure. (Rwelamila, Lobelo \& Ebohon, 1997; Agumba, Adegoke \& Otiena, 2005; Inuwa, Wanyona and Diang'a, 2014). Chilipunde (2007) opined that lack of technical skills required in project implementation, deficiency in understanding of the contract documentation and the preparation and submission of tenders are challenges facing small construction enterprises. This was corroborated by Kayanula and Quartey (2000) and Ramokolo and Smallwood (2008) where it was discovered that the lack of managerial know-how places significant constraints on small construction enterprise's development and growth.

\section{STATEMENT OF PROBLEMS}

In Nigeria, few companies' mainly foreign corporations control a large percentage of the total workload of the construction industry, while a large number of small and medium-sized enterprises, usually indigenous firms share a meager percentage of the construction workload (Idoro, 2004). According to Idoro (2010), much preference is given to expatriate managed contractors over their indigenous contractors in the award of construction contracts as they view their performance regarding the quality standard of work as being better than their indigenous counterparts. Idoro (2012) therefore advise that it is of a necessity for indigenous contractors to regain the confidence of clients by improving their performances. The problems of indigenous contractors were classified as both systemic and structural by Aniekwu and Okpala (1987). Notable among the challenges is lack of easy access to credit facilities (Adam, 1997), lack of a well-structured regulatory authority (Aibinu \& Odeyinka, 2006), and most importantly, continued dominance of the industry by the foreign contractors to the disadvantage of the indigenous ones (Oluwakiyesi, 2011) which is of more significance to this study.

NICE contracting operations are characterized by poor performance and lack competence when compared with their foreign counterparts, and this has adversely affected their involvement in the contracting business (Aibinu \& Jagboro, 2002). Another notable factor associated with NICE is the time overrun as observed by Mansfield, Ugwu and Doran (1994), which is the result of deficiencies in the productivity of NICE. According to Olomolaiye, Wahab, and Price (1987), some of the probable reasons for low patronage of NICE most especially in connection with high net-worth project procurement includes shortage in the availability and supply of adequate manpower and material resources, ambiguous process of construction execution, geographical effect of weather, inadequate monitoring of workers' activities, lack of dedication to duties by workers and difficulty of workers adapting to changes in construction module.

It is equally pertinent to note that the indigenous contractors are far less concerned about the welfare of their workers but rather, they place profit margin above reward for excellence. This often has led to the liquidation of their businesses, absenteeism of workers from their post, abandonments and inconclusive contract execution, and time overrun (Uwakweh, 2002). According to Nwachukwu (1998), workers who found themselves in the construction business at the local level were laced with an environment that was not conducive for a high level of productivity and work efficiency.

The few foreign construction firms that have enjoyed more patronage and capacity development take advantage of the weaknesses of NICE. A study by Aniekwu and Audu (2010) revealed that foreign construction contractors make up 5 percent of the total population of registered contractors while their indigenous counterparts are 95 percent of the population. However, the foreign contractors were awarded the majority of the high networth jobs. These and many other factors have placed the NICE at a disadvantage with little or no patronage in the procurement of high net-worth project when compared with the foreign contractors as enormous demand for infrastructural needs in the country has attracted a lot of resources from the international contractors - investing heavily in areas such as information technology, communications, as well as the construction industry. 
Given the above challenges, the relevance of NICE cannot be discarded, according to Onugu (2005), Small and Medium Enterprises (SMEs) is of importance in every developing country as they contribute significantly to the growth and development of the economy. SMEs are referred to as "the engine of growth" and "catalysts for socio-economic transformation of any country. They are the veritable vehicle for the achievement of national economic objectives of employment generation and poverty reduction as well as the development of entrepreneurial abilities including indigenous technology. SMEs provide a veritable platform for the development of the competencies of new graduates before they are absolved into the mainstream of the industry by the high flyers.

Adams (1997) opined that concerted efforts have been geared at promoting indigenous contractor's involvement and increase their participation in the industry, however, the efforts have not been successful. This necessitated a study on the challenges facing NICE with the view that the outcome of the study will provide information for government and other stakeholders to recognise major barriers in the development of the contracting capacity of NICE.

The objectives of this study are two folds: the first is to identify the factors responsible for the low patronage of indigenous construction firms, while the second is to determine how indigenous contractors can improve their level of patronage by clients.

\section{SIGNIFICANCE OF THE STUDY}

The importance of this study is to expose the difficulties faced by indigenous construction enterprise. NICE is very important to the economy as they contribute to the employment rate of the country's workforce and are therefore an important factor in the Nigerian economy. Identifying the challenges faced by NICE will help prevent the rate of NICE business failures as this will better position NICE to compete favorably with the foreign contractors. The practice of awarding contracts to foreigners' managed contractors according to Idoro (2010) is a major concern to stakeholders in the construction industry because it does not promote indigenous integration, capacity building and technological advancement in the local construction industry and it is a drain on the nation's scarce forex resources. It will help the government at all levels to adopt strategies to help develop the contracting capacities of NICE and help reduce the high business failure rates of NICE and prevents the capital flight of Nigeria's forex to expatriates country of origin.

\section{LITERATURE ON CHALLENGES ON INDIGENOUS CONSTRUCTION ENTERPRISES IN AFRICA}

The challenges of infrastructure development in Africa are huge, insufficient infrastructure continues to be a major obstacle towards Africa realizing its full economic potentials. However, the high net-worth construction projects are executed by foreign-registered or foreigner's managed construction enterprises. Indigenous construction enterprises in Africa and Nigeria in particular offer little or no competition to their foreign counterparts. Jaafar and Abdul-Aziz, (2005) described the majority of indigenous construction enterprises in Africa as being largely unregistered, operate in the informal sector of the economy and have very little formal business systems. This assertion was corroborated by Saka and Ajayi (2010) who opined that NICE operates as sole trader-type entrepreneurs with little knowledge of the workings of the construction system. They constitute the largest percentage of total contractors and employ very few permanent staff, usually less than ten employees. They often do not have office premises, equipment or a permanent workforce. Indigenous construction enterprise is either family-owned business or solely owned in which the business dies when the owner is no more.

Agwu and Emeti (2014) in their study on issues, challenges, and prospects of SMEs in Nigeria found that poor financing, inadequate social infrastructures, lack of managerial skills and multiple taxations were major challenges confronting SMEs. In a similar study by Fatai (2014), he examines the problems and prospects of small building contractors in Nigeria and identified that financial problems, government unfavorable fiscal policy, poor management practice, poor accounting standards, shortage of manpower, financial indiscipline and corruption were the major challenges of NICE. Adekoya (2016) opined that SMEs have not been able to play the expected vital role expected of them for economic growth and development, this is due to multiple taxation system, high 
cost of legal documentation, inadequate capacity building, difficulties encountered in obtaining credit facilities, corruption, and unstable government policies.

Laryea (2010) investigated the challenges and opportunities being faced by contractors in Ghana and found that difficulties in securing financing for projects and a harsh business environment are the main challenges faced by Ghanaian contractors. In a study on issues facing small Egyptian construction firms, Hassanein and Adly (2008) found that lack of access to suitable sources of finance was a barrier to the growth of small construction firms. Bala, Bello, Kolo, and Bustani (2009) identified unfavourable business environment, weak economy, lack of enabling policies, corruption, and poor government patronage as the bane of the growth of local construction firms in Nigeria. Adams (1995) in his study of the constraints on contractors' performance and development identified uncertainties in supplies and prices of materials, delayed interim payments, additional works and lack of capital as the major perceived constraints.

In a study by Well (1998), it was observed that some of the challenges besetting indigenous construction enterprise in Africa include: the low levels of training of personnel, poor organisation of the construction industry, a large number of small and inefficient firms, lack of planning at all levels of the construction process. Materu (2000) noted that lack of exposure, erosion of capital and eventual loss of confidence has suppressed the growth of the indigenous contractors. He noted that most local contractors lack exposure to modern construction management techniques, experience and confidence in the management of medium to large projects. This results in low patronage which according to Holt (2013) triggers the failure of the construction enterprise.

\section{METHODOLOGY}

Debois (2016) asserted that questionnaires are cost-efficient, practical, gives speedy results, maintains user anonymity, and can cover all aspects of a topic. Therefore, a questionnaire was used to elicit information from consultants and clients involved in construction activities in Lagos state. The questionnaires were administered in person to the respondents by the researcher and two trained research assistants. The survey questions were designed in a manner such that the questions were simple and unambiguous. The target population for this study is the primary stakeholders involved in construction projects in Lagos metropolis, Nigeria. This includes public and private sector clients and consultants.

The design of the questionnaire for this study was structured and multiple-choice type. The survey consists primarily of three parts:

a) Section A: respondents' background information: this section consists of six questions aimed at assessing the suitability and reliability of the responses from the respondents for the study. It focuses on the form of ownership of the respondents' firm, their organisation type, professional background, minimum academic qualification, industry's experience and types of projects involved.

b) Section B: challenges being faced by indigenous contractors. 25 factors were identified, and the respondents were asked to rank these factors based on their experience on previous projects using a Likert scale of $1-5$ with 1 being the lowest perception (not important) and 5 being the highest (very important)

c) Section $\mathrm{C}$ : how to improve the performance of indigenous contractors. 18 factors were identified, and the respondents were asked to rank these factors based on their experience on previous projects using a Likert scale of $1-5$ with 1 being the lowest perception (least impact) and 5 being the highest (very high impact).

Data collected were analyzed using descriptive statistics for the respondent's background information. Mean score was used for the ranking of identified 25 and 18 factors on challenges being faced by indigenous contractors on how to improve the performance of indigenous contractors respectively. Kruskal-Wallis test was employed to determine whether there is a statistically significant difference in the perception of respondents in the ranking of these factors. 


\section{RESULTS AND DISCUSSIONS \\ 6.1 General information}

Table 1 presents the distribution of questionnaires administered to the respondents. The table shows a total of 98 questionnaires were administered, out of which 76 were retrieved representing 77.55 percent. The breakdown of respondents shows that there was 71.62 percent response rate by consultants while the response rate of clients was 67.65 percent.

Table 1: Distribution of the questionnaire

\begin{tabular}{|l|c|c|c|}
\hline \multicolumn{1}{|c|}{ Stakeholders category } & $\begin{array}{c}\text { Number of questionnaires } \\
\text { administered }\end{array}$ & $\begin{array}{c}\text { Number of questionnaires } \\
\text { returned }\end{array}$ & Percent \\
\hline Consultants & 74 & 53 & 71.62 \\
\hline Client & 34 & 23 & 67.65 \\
\hline Total & 98 & 76 & 77.55 \\
\hline
\end{tabular}

Table 2 reveals respondents' background information; it reveals that there were 53 consultants and 23 clients in the 76-total responses obtained. It further shows that the most response came from respondents with bachelor's degree with 48.7 percent of which there were 25 consultants and 12 clients with bachelor's degree. The industry experience shows that respondents with 11-15years of experience constitute the most respondents with the calculated average years of experience of 11years for all the respondents. Because of the characteristics of the respondents as provided by this information, responses from the respondents were considered reliable and realistic.

Table 2: Background information of respondents'

\begin{tabular}{|l|c|c|c|}
\hline \multicolumn{1}{|c|}{ Respondents profile } & Consultants & Clients & All \\
\hline Form of ownership & & & $72(94.7)$ \\
\hline Indigenous & $49(92.5)$ & $23(100)$ & $4(5.3)$ \\
\hline Foreign & $4(7.6)$ & $0(0)$ & $76(100)$ \\
\hline Total & $53(100)$ & $23(100)$ & \\
\hline Educational Qualification & & & $1(1.3)$ \\
\hline National Diploma & $1(1.9)$ & $0(0)$ & $32(42.1)$ \\
\hline Higher National Diploma & $24(45.3)$ & $8(34.8)$ & $37(48.7)$ \\
\hline Bachelor of Science & $25(47.2)$ & $12(52.2)$ & $5(6.6)$ \\
\hline Master of Science. & $3(5.7)$ & $2(8.7)$ & $1(1.3)$ \\
\hline Doctor of Philosophy & $0(0)$ & $1(4.3)$ & $76(100)$ \\
\hline Total & $53(100)$ & $23(100)$ & $2(2.6)$ \\
\hline Industry Experience & & & $32(42.1)$ \\
\hline 0-5years & $1(1.9)$ & $1(4.3)$ & $34(44.7)$ \\
\hline 6-10years & $24(45.3)$ & $8(34.8)$ & $7(9.2)$ \\
\hline 11-15years & $23(43.4)$ & $11(47.8)$ & $1(1.3)$ \\
\hline 16-20years & $5(9.4)$ & $2(8.7)$ & $\mathbf{7 6}(\mathbf{1 0 0})$ \\
\hline Above 20years & $53(100)$ & $1(4.3)$ & $\mathbf{2 3 ( 1 0 0 )}$ \\
\hline Total & $\mathbf{5 3}$ & & \\
\hline
\end{tabular}

\subsection{Challenges faced by Nigeria indigenous contractor enterprises}

Table 3 present the challenges faced by NICE based on the rankings of 25 identified factors. The analysis of the results based on the overall mean score of both consultants and clients show that the five leading challenges being faced by indigenous contractor are: (i) Limited technical expertise, (ii) Insufficient profit on projects, (iii) Delay in the payment of contractors for work done (iv) poor tender preparation and estimation, and (v) Limited trained manpower with mean score values of 3.09, 3.00, 2.99, 2.97 and 2.95 respectively. 
Table 3: Challenges faced by NICE

\begin{tabular}{|c|c|c|c|c|c|c|c|c|c|c|}
\hline \multirow{3}{*}{ NICE challenges } & \multicolumn{3}{|c|}{ Overall } & \multicolumn{3}{|c|}{ Consultants } & \multicolumn{3}{|c|}{ Client } & \multirow{3}{*}{$\begin{array}{c}\text { Kruskal- } \\
\text { Wallis } \\
\text { Sig. }\end{array}$} \\
\hline & \multicolumn{3}{|c|}{$\mathrm{N}=74$} & \multicolumn{3}{|c|}{$\mathrm{N}=55$} & \multicolumn{3}{|c|}{$\mathrm{N}=19$} & \\
\hline & Mean & $\begin{array}{l}\text { Std. } \\
\text { Dev. }\end{array}$ & Rank & Mean & $\begin{array}{l}\text { Std. } \\
\text { Dev. }\end{array}$ & Rank & Mean & $\begin{array}{l}\text { Std. } \\
\text { Dev. }\end{array}$ & Rank & \\
\hline limited technical expertise & 3.09 & 0.912 & 1 & 3.04 & 0.980 & 2 & 3.22 & 0.736 & 1 & 0.239 \\
\hline insufficient profit on projects & 3.00 & 0.894 & 2 & 3.00 & 0.920 & 3 & 3.00 & 0.853 & 3 & 0.933 \\
\hline $\begin{array}{l}\text { delay in the payment of contractors for work } \\
\text { done }\end{array}$ & 2.99 & 0.916 & 3 & 3.06 & 0.949 & 1 & 2.83 & 0.834 & 7 & 0.292 \\
\hline poor tender preparation and estimation & 2.97 & 0.832 & 4 & 2.94 & 0.842 & 5 & 3.04 & 0.825 & 2 & 0.552 \\
\hline limited trained manpower & 2.95 & 0.893 & 5 & 2.94 & 0.908 & 5 & 2.96 & 0.878 & 4 & 0.913 \\
\hline poor managerial skills & 2.95 & 1.044 & 6 & 3.00 & 1.160 & 3 & 2.83 & 0.717 & 7 & 0.816 \\
\hline $\begin{array}{l}\text { inadequate project planning and management } \\
\text { of the design process }\end{array}$ & 2.87 & 0.971 & 7 & 2.91 & 1.024 & 7 & 2.78 & 0.850 & 9 & 0.723 \\
\hline lack of skilled craftsmen & 2.82 & 0.890 & 8 & 2.85 & 0.928 & 8 & 2.74 & 0.810 & 10 & 0.624 \\
\hline $\begin{array}{l}\text { lack of stable and harmonious relations } \\
\text { between employers and employees }\end{array}$ & 2.78 & 0.988 & 9 & 2.81 & 0.942 & 11 & 2.70 & 1.105 & 12 & 0.685 \\
\hline poor recruitment and selection techniques & 2.76 & 0.781 & 10 & 2.83 & 0.826 & 10 & 2.61 & 0.656 & 15 & 0.273 \\
\hline poor human resource policy & 2.76 & 1.031 & 11 & 2.85 & 1.008 & 8 & 2.57 & 1.080 & 16 & 0.228 \\
\hline high patronage of foreign firms & 2.72 & 1.001 & 12 & 2.66 & 0.854 & 17 & 2.87 & 1.290 & 6 & 0.771 \\
\hline unavailability of loan scheme & 2.72 & 0.873 & 13 & 2.79 & 0.906 & 13 & 2.57 & 0.788 & 16 & 0.301 \\
\hline high cost of materials & 2.68 & 0.804 & 14 & 2.81 & 0.786 & 11 & 2.39 & 0.783 & 20 & 0.089 \\
\hline lack of proper project planning & 2.68 & 0.941 & 15 & 2.57 & 0.971 & 20 & 2.96 & 0.825 & 4 & 0.059 \\
\hline high cost of labour & 2.67 & 0.839 & 16 & 2.68 & 0.915 & 16 & 2.65 & 0.647 & 13 & 0.936 \\
\hline lack of skilled of labour & 2.67 & 0.870 & 17 & 2.64 & 0.857 & 18 & 2.74 & 0.915 & 10 & 0.640 \\
\hline unavailability of funds & 2.66 & 1.014 & 18 & 2.79 & 1.026 & 13 & 2.35 & 0.935 & 21 & 0.053 \\
\hline high cost of plants and equipment & 2.63 & 1.005 & 19 & 2.75 & 0.979 & 15 & 2.35 & 1.027 & 21 & 0.180 \\
\hline poor training strategy of employees & 2.58 & 0.868 & 20 & 2.55 & 0.911 & 21 & 2.65 & 0.775 & 13 & 0.530 \\
\hline lack of entrepreneurial skills & 2.57 & 0.789 & 21 & 2.58 & 0.795 & 19 & 2.52 & 0.790 & 19 & 0.960 \\
\hline lack of marketing and sales strategies & 2.47 & 0.986 & 22 & 2.43 & 1.010 & 24 & 2.57 & 0.945 & 16 & 0.350 \\
\hline provision of social protection where needed & 2.41 & 0.836 & 23 & 2.49 & 0.846 & 22 & 2.22 & 0.795 & 23 & 0.383 \\
\hline lack of vision & 2.36 & 0.919 & 24 & 2.45 & 0.992 & 23 & 2.13 & 0.694 & 25 & 0.178 \\
\hline unclear language among project stakeholders & 2.33 & 1.012 & 25 & 2.38 & 1.078 & 25 & 2.22 & 0.850 & 23 & 0.669 \\
\hline
\end{tabular}

$\mathrm{N}=$ number

The least ranked factors are (i) lack of entrepreneurial skills, (ii) lack of marketing and sales strategies, (iii) provision of social protection where needed, (iv) lack of vision, and (v) unclear language among project stakeholders with means score values of 2.57, 2.47, 2.41, 2.36, and 2.33 respectively. These findings are in contrast with few other studies. For instance, Adams (1997) identified uncertainties in supplies and prices of material, obtaining interim payment and procuring works as the highest rank factors, while personnel management and providing quality workmanship were the least identified constraints to indigenous contractor's performance.

Laryea (2010) identified delays in payment and poor design as the challenges facing contractors in Ghana. Kulemeka, Kukulanga and Morton (2015) identified high lending interest regimes offered by financial institutions as the highest inhibiting performance of small- and medium-scale contractors in Malawi. It can therefore be deduced that there are so many challenges confronting indigenous contractors in Africa.

The table further presents the ranking of these factors based on the perception of consultants and clients separately. The ranking of the 5 most important factors by consultants in descending order of importance includes: (i) delay in the payment of contractors for work done (ii) limited technical expertise, (iii) insufficient profit on projects (iv) poor managerial skills, and (v) poor tender preparation and estimation.

In the perception of the clients, the clients see limited technical expertise as the most important challenge facing indigenous contractors and ranked it the highest $\left(1^{\text {st }}\right)$, while poor tender preparation and estimation, insufficient profit on projects ranked $2^{\text {nd }}, 3^{\text {rd }}$. Limited trained manpower and lack of proper project planning were ranked $4^{\text {th }}$ with a mean score value of 2.96 .

From the analysis as presented, consultants and clients agree that limited technical expertise is the most important challenge affecting the performance of indigenous contractors. Insufficient profit on projects and delay in the payment of contractors for work done were ranked $2^{\text {nd }}$ and $3^{\text {rd }}$ respectively by consultants. However, clients opined that poor tender preparation and insufficient profit on projects are the next challenges that beset the performance of indigenous contractors and were ranked $2^{\text {nd }}$ and $3^{\text {rd }}$ respectively. 
In an attempt to determine if there was any statistical difference in the perception of consultants and clients, the Kruskal-Wallis test was conducted at a significance level of 5\%. The result shows that there is no statistically significant difference in the perceptions of respondents on the challenges being faced by indigenous contractors as the p-value of all the factors is greater than 0.05 . This implies that both consultants and clients are consistent in their ranking of these factors.

\subsection{Performance of Nigeria indigenous contractor enterprises}

Table 4 presents the ranking of respondents on how to improve the performance of NICE, from the table, application of project management techniques in construction activities was ranked the highest as the most significant factor to improve the performance of indigenous contractors with a mean score value of 3.14. Quality control of materials, improving production capabilities, hiring and training of top professional, and embarking on continuous training in raising the skills level of the staff were the other factors ranked with means of 3.01, 2.96, 2.92 and 2.91respectively.

Table 4: How to improve the performance of indigenous contractors

\begin{tabular}{|c|c|c|c|c|c|c|c|c|c|c|}
\hline \multirow{3}{*}{ Performance improvement factors } & \multicolumn{3}{|c|}{ Overall } & \multicolumn{3}{|c|}{ Consultants } & \multicolumn{3}{|c|}{ Client } & \multirow{3}{*}{$\begin{array}{l}\text { Kruskal- } \\
\text { Wallis } \\
\text { Sig. }\end{array}$} \\
\hline & \multicolumn{3}{|c|}{$\mathrm{N}=74$} & \multicolumn{3}{|c|}{$\mathrm{N}=55$} & \multicolumn{3}{|c|}{$\mathrm{N}=19$} & \\
\hline & Mean & $\begin{array}{l}\text { Std. } \\
\text { Dev. }\end{array}$ & Rank & Mean & $\begin{array}{l}\text { Std. } \\
\text { Dev. }\end{array}$ & Rank & Mean & $\begin{array}{l}\text { Std. } \\
\text { Dev. }\end{array}$ & Rank & \\
\hline $\begin{array}{l}\text { application of project management techniques in } \\
\text { construction activities }\end{array}$ & 3.14 & 2.420 & 1 & 3.02 & 1.009 & 2 & 3.43 & 4.176 & 1 & 0.319 \\
\hline quality control of materials & 3.01 & 0.931 & 2 & 3.04 & 0.960 & 1 & 2.96 & 0.878 & 3 & 0.766 \\
\hline improving production capabilities & 2.96 & 0.944 & 3 & 3.02 & 1.009 & 2 & 2.83 & 0.778 & 8 & 0.503 \\
\hline hiring and training of top professional & 2.92 & 0.860 & 4 & 3.02 & 0.909 & 2 & 2.70 & 0.703 & 15 & 0.174 \\
\hline $\begin{array}{l}\text { embarking on continuous training in raising the } \\
\text { skills level of the staff }\end{array}$ & 2.91 & 1.035 & 5 & 2.94 & 1.008 & 5 & 2.83 & 1.114 & 10 & 0.476 \\
\hline employment of competent personnel & 2.91 & 0.941 & 6 & 2.89 & 0.934 & 6 & 2.96 & 0.976 & 3 & 0.777 \\
\hline easy access to plant and equipment & 2.89 & 0.776 & 7 & 2.87 & 0.761 & 7 & 2.96 & 0.825 & 3 & 0.664 \\
\hline adopting an integrated approach to construction & 2.86 & 0.919 & 8 & 2.72 & 0.907 & 13 & 3.17 & 0.887 & 2 & $0.029 *$ \\
\hline $\begin{array}{l}\text { the use of ICT to improve the performance by } \\
\text { making workflow easier }\end{array}$ & 2.84 & 0.910 & 9 & 2.81 & 0.878 & 8 & 2.91 & 0.996 & 6 & 0.872 \\
\hline investing in knowledge management & 2.79 & 0.805 & 10 & 2.79 & 0.863 & 9 & 2.78 & 0.671 & 10 & 0.985 \\
\hline establishing a sound basis for effective scheduling & 2.79 & 0.838 & 11 & 2.77 & 0.869 & 10 & 2.83 & 0.778 & 8 & 0.712 \\
\hline $\begin{array}{l}\text { adherence to project management procedures by } \\
\text { client and consultant }\end{array}$ & 2.76 & 0.964 & 12 & 2.75 & 0.897 & 12 & 2.78 & 1.126 & 11 & 0.641 \\
\hline providing incentives for merger and acquisition & 2.75 & 0.850 & 13 & 2.77 & 0.891 & 10 & 2.70 & 0.765 & 15 & 0.724 \\
\hline $\begin{array}{l}\text { adoption of a wide range of concept, tools, and } \\
\text { techniques to enhance collaboration and improve } \\
\text { efficiency and quality }\end{array}$ & 2.74 & 0.915 & 14 & 2.68 & 0.779 & 14 & 2.87 & 1.180 & 7 & 0.837 \\
\hline provision of long term loans & 2.70 & 0.817 & 15 & 2.68 & 0.728 & 14 & 2.74 & 1.010 & 13 & 0.922 \\
\hline $\begin{array}{l}\text { adopting precise computerize models for the } \\
\text { selection of the most qualified staff }\end{array}$ & 2.64 & 0.795 & 16 & 2.62 & 0.814 & 16 & 2.70 & 0.765 & 15 & 0.340 \\
\hline $\begin{array}{l}\text { improving industry practices by using computer } \\
\text { technology to integrate the construction process }\end{array}$ & 2.64 & 0.812 & 17 & 2.60 & 0.817 & 17 & 2.74 & 0.810 & 13 & 0.457 \\
\hline development of alternative procurement strategy & 2.54 & 0.840 & 18 & 2.58 & 0.819 & 18 & 2.43 & 0.896 & 18 & 0.442 \\
\hline
\end{tabular}

$\mathbf{N}=$ number

The least factors that can improve the performance of indigenous contractor by the respondents are (i) adoption of wide range of concept, tools, and techniques to enhance collaboration and improve efficiency and quality, (ii) provision of long term loans, (iii) adopting precise computerize models for the selection of the most qualified staff, (iv) improving industry practices by using computer technology to integrate the construction process, and (v) development of alternative procurement strategy with mean score values of 2.74, 2.70, 2.64, 2.64, and 2.54 respectively.

The findings of this study are similar to that of Sibiya, Aigbavboa, and Thwala (2015). It was identified that proper project planning and scheduling, use of effective project management techniques are measures to improve the performance of construction projects in South Africa. 
Further evaluation of the responses was done by comparing the group mean of the consultants and the clients separately. The ranking by consultants of the two most important factors was (i) quality control of materials and (ii) application of project management techniques in construction activities. Clients, however, ranked application of project management techniques in construction activities $1^{\text {st }}$ and adopting an integrated approach to construction $2^{\text {nd }}$. The development of alternative procurement strategy was considered the least relevant factor that can improve the performance of indigenous contractors by both the consultants and the clients. To determine if there is a statistically significant difference in perceptions of the both consultant's and client's responses on the ranking of the 18 factors, the Kruskal-Wallis test was conducted at a significance level of 5\%. Based on the results of the Kruskal-Wallis test, the results show that except for 1 of the factor out of 18 identified performance improvement factors, there is no statistically significant difference in the perceptions of consultants and clients on how to improve the performance of indigenous contractors. The factors where there is a statistical difference in the perception of consultants and clients are adopting an integrated approach to construction.

This difference in opinion could be attributed to the training, skills, experience, and expertise of both the consultants and the clients. Consultants ranked this factor $13^{\text {th }}$ while clients ranked it as the $2^{\text {nd }}$ most important factor the can improve the performance of indigenous contractors.

\section{CONCLUSIONS}

Nigeria's Indigenous Construction Enterprise is important to the economy of the country. The huge deficit in Nigeria's infrastructure is to their advantage. This will rekindle patronage only if the challenges presently being faced by NICE are quickly surmounted by the increase in NICE's project performance capability. SMEs in which NICE is classified is renowned as the engine of "growth" and "catalysts" for the socio-economic transformation of any country of which the present government is fully aware. However, the performance of NICE in terms of project delivery to budget, schedule, and management practices; required quality standard and stakeholders' satisfaction among others will determine their level of patronage by public and private clients. This study identified 25 challenges and 18 ways of improving the performance of indigenous contractors. Thus, the overall rankings of the challenges among project stakeholders of clients and consultants revealed that: limited technical expertise, insufficient profit on projects, delay in the payment of contractors for work done, poor tender preparation and estimation, limited trained manpower, poor managerial skills, inadequate project planning and management of the design process were the top six barriers. On the performance improvement of indigenous contractors, the study found that application of project management techniques in construction activities, quality control of materials, improving production capabilities, hiring and training of top professional, embarking on continuous training in raising the skills level of the staff, employment of competent personnel and easy access to plant and equipment where rank the highest.

It is concluded that the ability of NICE to compete effectively with their foreigners' managed construction enterprises will likely bring down the cost of construction. This will open the competition nest for many construction practitioners. As it stands, the small number of foreign contracting firms operation is responsible for over 95 percent of high net-worth construction projects; as such the market is monopolized by these firms as they use this to their advantage in terms of their tender prices in the face of little or no competition. Should NICE be able to improve on its managerial competence, technology, methodology, aces to finance and acquire relevant equipment; this will boost its patronage and will reinforce the trust of contracting clients in them. This patronage will help to prevent capital flights of the nation's scares foreign exchange.

\section{REFERENCES}

Adams, O. A. (1995). Indigenous contractors' perceptions of the constraints on contractors' performance and development programmes required in Nigeria. Habitat International. 19(4), 599-613.

Adams, O.A. (1997). Contractor development in Nigeria: Perceptions of contractors and professionals. Construction Management and Economics, 15(1), 95-108.

Adekoya, A. (2016, June 20). Problems and prospects of SME's in Nigeria. Information Guide Nigeria. Retrieved January 8, 2018 from https://infoguidenigeria.com/problems-prospects-smes-nigeria/ 
Agumba, J. N., Adegoke, I. O. \& Otiena, F. (2005). Evaluating project management techniques in small and medium enterprises delivering infrastructure in South Africa construction industry. Proceedings of 3rd Postgraduate Conference 2005. Construction Industry Development, Eskom Convention Center, Midrand, Johannesburg, South Africa, 9th-11th October:52-65.

Agwu, M. O. \& Emeti, C. I. (2014). Issues, challenges, and prospects of small and medium scale enterprises (SMEs) in Port-Harcourt city, Nigeria. European Journal of Sustainable Development, 3(1), 101-114.

Aibinu, A. and Odeyinka, H. A. (2006). Construction delays and their causative factors in Nigeria, Journal of Construction Engineering and Management, 132 (7), 667-677.

Aibinu, A., \& Jagboro, G. (2002). The effects of construction delays on project delivery in Nigerian construction industry. International Journal of Project Management, 20(8), 593-99.

Akintunde, I. (2003). The Nigerian Construction Industry: Past, Present, Problems and Prospects: Ibadan University Printery

Aniekwu, A. N., \& Audu, H. O. (2010). The effects of management on productivity: a comparative study of indigenous and foreign firms in the Nigerian construction industry. Proceedings of West Africa Built Environment (WABER)Conference, 27-18 July 2010, (pp. 567-578). Accra-Ghana: WABER.

Aniekwu, A.N. \& Okpala, D.C. (1987) Contractual arrangements and the performance of the Nigerian construction industry (the structural components). Construction Management and Economics 6(1), 3-11.

Bala, K., Bello, A., Kolo, B. A., \& Bustani, S. A. (2009). Factors inhibiting the growth of local construction firms in Nigeria. Procs 25th ARCOM Conference, 7-9 September.

Chilipunde, R. L. (2010). Constraints and challenges faced by small, medium and micro-enterprise contractors in Malawi: A thesis submitted to the Faculty of Engineering, the Built Environment and Information Technology, Nelson Mandela Metropolitan University, School of the Built Environment.

Debois, S. (2016). 9 advantages and disadvantages of questionnaires. Retrieved January 7, 2018, from https://surveyanyplace.com/questionnaire-pros-and-cons/

Fatai (2005). Small and medium scale enterprises in Nigeria: the problems and prospects. Asian Journal of Social Sciences, 13, 12-23

Hassanein, A. A. G. \& Adly, S. W. (2008). Issues facing small Egyptian construction firms: the financing barrier. Journal of Small Business \& Entrepreneurship, 21(3), 363-376.

Holt, G. D. (2013). Construction business failure: Conceptual synthesis of causal agents. Construction Innovation, $13(1), 50-76$.

Idoro, G. I. (2004). The effect of globalisation on safety in the construction industry in Nigeria. Proceedings: The International Symposium on Globalisation and Construction. School of Civil Engineering, Asian Institute of Technology, Bangkok, Thailand, November.

Idoro, G. I. (2010). Influence of quality performance on clients' patronage of indigenous and expatriate construction contractors in Nigeria. Journal of Civil Engineering and Management, 16(1), 65-73.

Idoro, G. I. (2012). Influence of the monitoring and control strategies of indigenous and expatriate Nigerian contractors on project outcome. Journal of Construction in Developing Countries, 17(1), 49-67.

Inuwa, I. I., Wanyona, G. \& Diang'a, S. (2014). Construction procurement systems: Influencing factors for Nigerian indigenous contractors project planning. International Journal of Engineering Research and Technology, 3(4): 1043-1050. 
Jaafar, M. \& Addul-Aziz, A. R. (2005). Resource-based view and critical success factors: A study on Small and Medium-Sized Contracting Enterprises (SMCEs) in Malaysia. International Journal of Construction Management, 5(2),61-77.

Kayanula, D. \& Quartey, P. (2000). The policy environment for promoting small and medium-sized enterprises in Ghana and Malawi. Institute for Development Policy and Management, University of Manchester, Manchester, Working Series Paper 15. www.devinit.org/findev/Fd-wp15

Laryea, S. (2010). Challenges and opportunities facing contractors in Ghana. In: Laryea, S., Leiringer, R. and Hughes, W. (Eds) Procs West Africa Built Environment Research (WABER) Conference, 27-28 July 2010, Accra, Ghana, 215-226.

Mansfield, N. R., Ugwu, O. O., and Doran, T. (1994). Causes of delay and cost overruns in Nigerian construction projects. International journal of project management, 12(4) 254-260.

Materu, S. (2000). Towards sustainable local contracting capacity-CRB approach. Proceedings: The 2nd International Conference on Construction in Developing Countries. Gaborone, Botswana, 15-17 November

Norusis, M. J. (2000). SPSS 10.0 guide to data analysis, Prentice Hall, Englewood Cliffs, N.J

Nwachukwu, C. C. (1998.) Management, theory and practice. Onitsha: African, Onitsha, Nigeria: FEP publishers.

Ogbebor, P.O. (2002). Enhancing indigenous construction industry as a National goal in Nigerian development. In I. Akintunde (Ed.), The Nigerian Construction Industry: Past, Present, Problems and Prospects (pp.230239). Ibadan: Ibadan University Printery.

Ogunlana, S.O., Promkuntong, K. and Jearkjirm, V. (1996). Construction delays in a fast-growth economy; comparing Thailand with other economies. International Journal of Project Management, 14(1), 37-45.

Olomolaiye, P.O., Wahab, K. A. \& Price, A. D. F. (1987). Problems influencing craftsmen's productivity in Nigeria. Building and Environment, 22(4),317-323.

Oluwakiyesi, T. (2011). Nigerian construction industry: A haven of Opportunities. Lagos, Nigeria: Vetiva Capital Management Limited.

Onugu, B. A. (2005). Small and medium enterprises (SMEs) in Nigeria: Problems and prospects. (Doctoral dissertation, St. Clements University). Retrieved from http://stclements.edu/grad/gradonug.pdf

Oseni, F. A. (2002). Need to revive our national development Plans. In I. Akintunde (Ed.), The Nigerian Construction Industry: Past, Present, Problems and Prospects (pp.17-55).Ibadan: Ibadan University Printery.

Ramokolo, B. \& Smallwood, J. (2008). The capacity of emerging civil engineering contractors. ACTA Structilia, $15(2), 45-74$.

Rwelamila, P. D., Lobelo, L. \& Ebohon, J. (1997). Factors associated with insolvencies amongst civil engineering contractors in South Africa. Proceedings of the 2nd International RICS COBRA Research Conference University of Portsmouth. United Kingdom.

Saka, N. \& Ajayi, O. M. (2010). A comparative assessment of incentive scheme between indigenous and multinational construction contractors in Nigeria. In: Egbu, C. (Ed) Procs 26th Annual ARCOM Conference, 6-8 September 2010, Leeds, UK, Association of Researchers in Construction Management, 583-591.

Sibiya, M., Aigbavboa, C. \& Thwala, W. D. (2015). Measures to improve the performance of construction projects in South Africa. Retrieved from http://hdl.handle.net/10210/72313. 
Uwakweh, B. O. (2002). Conceptual framework for motivating construction workers in developing countries. Proceedings of the 2nd International Conference of the CIB Task Group on Construction in Developing Countries, Faculty of Engineering and Technology, University of Botswana, Botswana, 15-17 Nov., pp3137.

Wells, J. (1998). The informal sector and the construction industry. First Meeting of TG29: Managing Construction Industry Development in Developing Countries, 21-23 Sept. 1998, AICC, Arusha, Tanzania.

Windapo, A. (2013) Fundamentals of Construction Management. Retrieved from http://bookboon.com/en/fundamentals-of-construction-management-ebook 